\title{
INVESTIGATION OF THE INFLUENCE OF ALLOYING ELEMENTS IN ZN-AL ALLOY ON THERMAL AND Mechanical Properties
}

\author{
Igor Kostolný, Roman Koleňák \\ Slovak University of Technology in Bratilsava, Faculty of Materials Science and Technology in Trnava, Institute of \\ Production Technologies Paulínska 16, 91724 Trnava, Slovak Republic
}

\begin{abstract}
The aim of work consist in the investigation of the influence of alloying elements in $\mathrm{Zn}-\mathrm{Al}$ alloy on thermal and mechanical properties. The $\mathrm{Zn}-\mathrm{Al}(1-5), \mathrm{Zn}-\mathrm{Al} 5-\mathrm{Cu}(1-3)$ and $\mathrm{Zn}-\mathrm{Al}-\mathrm{Mg}(1-3)$ solder alloys were used experiments. Solders were assessed by DSC analysis and by measuring tensile strength and hardness. It was found out that by adding of alloying elements, the melting temperature is decreasing. The opposite was observed in the case of $\mathrm{Zn}-\mathrm{Al} 5-\mathrm{Mg}(1-3)$ alloys. By increasing of wt. \% of $\mathrm{Al}$ in $\mathrm{Zn}-\mathrm{Al}(1-5)$ solder, the hardness and tensile strength was increased. In case of $\mathrm{Zn}$ $\mathrm{Al5}-\mathrm{Cu}(1-3)$ and $\mathrm{Zn}-\mathrm{Al} 5-\mathrm{Mg}(1-3)$ solder, decreasing of tensile strength and increasing of hardness was observed.
\end{abstract}

Keywords: solder alloy; melting temperature; tensile strength; hardness, soldering
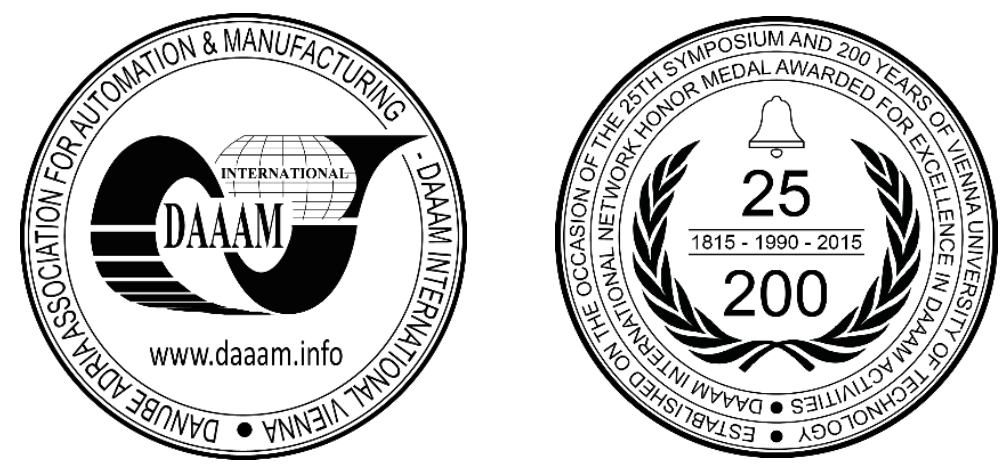

This Publication has to be referred as: Kostolny, I[gor] \& Kolenak, R[oman] (2016). Investigation of the Influence of Alloying Elements in Zn-Al Alloy on Thermal and Mechanical Properties, Proceedings of the 26th DAAAM International Symposium, pp.0699-0703, B. Katalinic (Ed.), Published by DAAAM International, ISBN 978-3-902734-07-5, ISSN 1726-9679, Vienna, Austria

DOI: $10.2507 / 26$ th.daaam.proceedings.096 


\section{Introduction}

As a result of EU directives of avoiding the use of lead [1] in solder joints, the attention of soldering at higher application temperatures is especially focused to trying to find most appropriate alloy as a substitute for $\mathrm{Pb}$-Sn solder. The research is focused mainly on $\mathrm{Zn}$ based solders with the addition of other elements to lower the melting temperature and improve their properties $[2,3,4,5]$. Because of the low price of zinc alloys, they are very attractive nowadays. The use of these solders is oriented not only to die-attaching but also for attaching optical components, circuit modules, in the automotive, aerospace industry and many others. Effect of the addition of rare earth (Er, Nd) on the structure and properties of $\mathrm{Sn}-\mathrm{Zn}$ solder dealt the authors of $[6,7]$. The results showed improvement in wettability, physical and strength properties. The investigation of properties of $\mathrm{Zn}$-Al based solders has been studied by the authors [8, 9, 10]. The addition of $\mathrm{Cu}$ resulted in the creation of intermetallic phase $\mathrm{CuZn} 4$. In the structure of eutectic solder, $\mathrm{Zn}$ - $\mathrm{Al}$ phase and basic $\mathrm{Zn}$ matrix were observed. Increasing the amount of $\mathrm{Cu}$ growing volume fraction of intermetallic phases CuZn4. Increasing the amount of $\mathrm{Al}$ resulted in increasing the formation of eutectic phase of the $\mathrm{Zn}-\mathrm{Al}$ and increasing micro hardness and tensile strength. The addition of $\mathrm{Mg}$ and $\mathrm{Ga}$ to $\mathrm{Zn}-\mathrm{Al}$ solder and investigation of its properties is dedicated by authors [11]. Solder was tested for die-attaching applications. The melting temperature of solder was lowered to $347^{\circ} \mathrm{C}$. Decreasing of micro-hardness with increasing temperature was observed. Authors [12] studied the fluxless soldering. The addition of $\mathrm{Ag}$ to the structure of $\mathrm{Zn}-6 \mathrm{Al}$ solder resulted witch creating of intermetallic phase AgZn3. The melting temperature of solder was $380^{\circ} \mathrm{C}$. The addition of In to the basic $\mathrm{Zn}$ solder and analyze its properties are dealt by authors $[13,14]$. A small amount of In to $\mathrm{Zn}-\mathrm{Al}$ solder decreases the melting temperature. It also resulted in an increase of electrical resistance compared to $\mathrm{Zn}-\mathrm{Al}$ eutectic solder. The contact angle of the $\mathrm{Al}$ and $\mathrm{Cu}$ substrate is reduced with increasing of In content. The overall analysis of influence of adding alloying elements $\mathrm{Al}, \mathrm{Cu}$ and $\mathrm{Mg}$ to $\mathrm{Zn}$ - $\mathrm{Al}$ solder is still not completely implemented. This paper therefore focuses on the study of changes in melting temperature, hardness and tensile strength depending of alloying elements.

\section{Experimental}

As the input component for the production of the solder alloy, materials of high purity of $3 \mathrm{~N}$ to $5 \mathrm{~N}$ are used. Manufacture of solder alloy was carried out in a vacuum oven. Alloys were cast into ingots. As a basis for the creation of ternary solders Zn-Al5 alloy was used due to higher concentrations of Al. The chemical composition of each alloy is shown in Tab. 1

\begin{tabular}{|c|c|c|c|c|}
\hline Chemical composition & $\begin{array}{c}\mathrm{Zn} \\
{[\mathrm{wt} . \%]}\end{array}$ & $\begin{array}{c}\mathrm{Al} \\
{[\mathrm{wt} . \%]}\end{array}$ & $\begin{array}{c}\mathrm{Cu} \\
{[\mathrm{wt} . \%]}\end{array}$ & $\begin{array}{c}\mathrm{Mg} \\
{[\mathrm{wt} . \%]}\end{array}$ \\
\hline $\mathrm{ZnAl1}$ & 99 & 1 & - & - \\
\hline $\mathrm{ZnAl} 2$ & 98 & 2 & - & - \\
\hline $\mathrm{ZnAl3}$ & 97 & 3 & - & - \\
\hline $\mathrm{ZnAl4}$ & 96 & 4 & - & - \\
\hline $\mathrm{ZnAl5}$ & 95 & 5 & - & - \\
\hline $\mathrm{ZnAl5Cu} 1$ & 94 & 5 & 1 & - \\
\hline $\mathrm{ZnAl} \mathrm{Cu} 2$ & 93 & 5 & 2 & - \\
\hline $\mathrm{ZnAl5Cu3}$ & 92 & 5 & 3 & - \\
\hline $\mathrm{ZnAl5Mg1}$ & 94 & 5 & - & 1 \\
\hline ZnAl5Mg2 & & 93 & - & 2 \\
\hline $\mathrm{ZnAl5Mg3}$ & & 92 & - & 3 \\
\hline
\end{tabular}

Table 1. Chemical composition of used solders

The alloys were prepared by normalized sizes and thoroughly cleaned of impurities to perform the static test of the tensile strength. Illustration of the test specimen in $\mathrm{mm}$ is shown in Fig. 1.

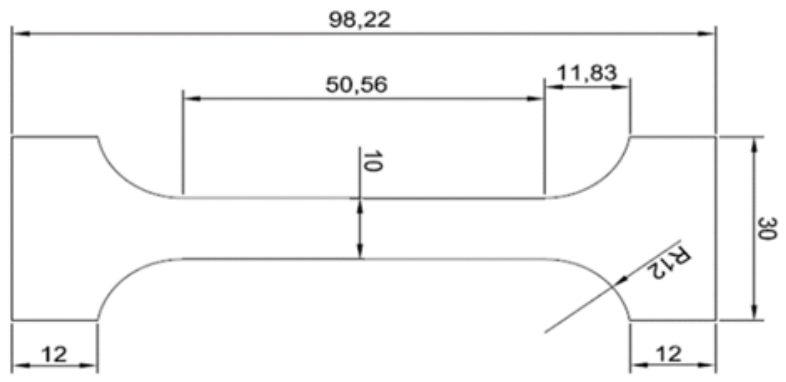

Fig. 1. Schematic of the specimen 
To measure the tensile strength, the LABORATECH LabTest 5250 SP1 equipment was used. Measurement of microhardness indentation of diamond consisted of regular tetrahedral pyramid (Vickers hardness). The actual measurements were carried out on the device BEUHLER indentata Met 1100. To carry out the DSC analysis, test samples weighing 3-8 grams were prepared.

\section{Experimental results}

DSC analysis was performed for understanding the thermal reactions of investigated solders during heating. The melting temperatures of $\mathrm{Zn}-\mathrm{Al}$ (1-5) solders are significantly changing depending on the quantity of Al. After reaching the composition of $\mathrm{Zn}-\mathrm{Al} 4$, the melting point had decreasing character. This composition is characterized as a eutectic melting temperature and reached $378.6^{\circ} \mathrm{C}$. After adding of next $1 \% \mathrm{Al}$, the temperature decrease to $380.5^{\circ} \mathrm{C}$. In the case of solders $\mathrm{Zn}-\mathrm{Cu}-\mathrm{Al} 5$ (1-3) was also observed decreasing character. The Lowest point reached $\mathrm{Zn}-\mathrm{Al} 5-\mathrm{Cu} 3 \mathrm{solder}$ with value $376.2^{\circ} \mathrm{C}$. The opposite was observed in the case of $\mathrm{Zn}-\mathrm{Al}$ - $\mathrm{Mg}$ (1-3) alloy. In this case was characterized increasing character and the highest melting temperature reached the $\mathrm{Zn}-\mathrm{Al} 5-\mathrm{Mg} 3$ solder with value of $342.9^{\circ} \mathrm{C}$.

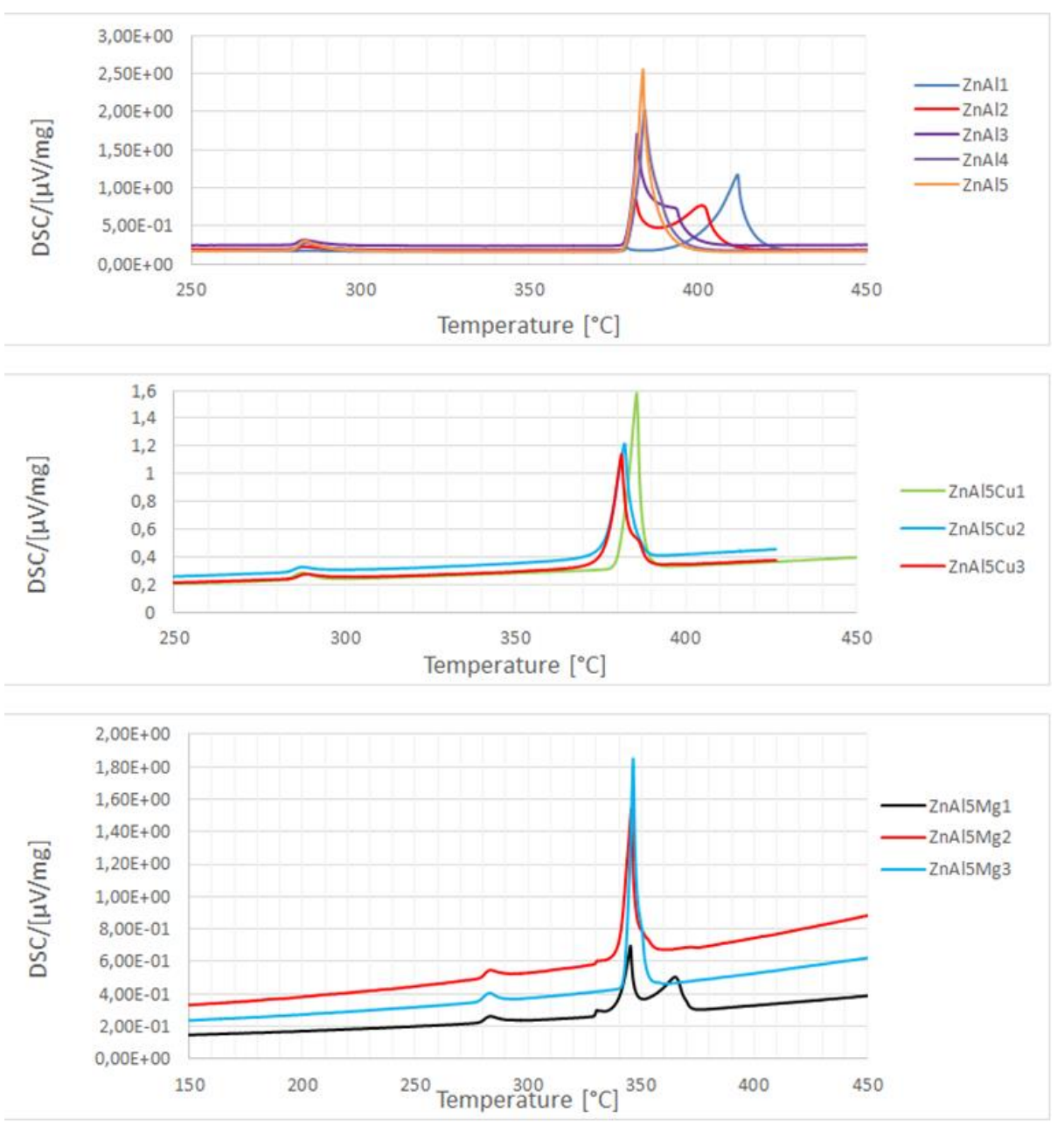

Fig. 2. DSC Analysis of examined solders

The melting temperatures of examined solders are shown in tab. 2 .

\begin{tabular}{lccc}
\hline Solder & Melting temperature $\left[{ }^{\circ} \mathbf{C}\right]$ & Solder & Melting temperature $\left[{ }^{\circ} \mathbf{C}\right]$ \\
\hline ZnAl1 & 400,8 & ZnAl5Cu1 & 380.9 \\
\hline ZnAl2 & 379,3 & ZnAl5Cu2 & 376.4 \\
\hline ZnAl3 & 378,3 & ZnAl5Cu3 & 376.2 \\
\hline ZnAl4 & 378,6 & ZnAl5Mg1 & 339,1 \\
\hline ZnAl5 & 380,5 & ZnAl5Mg2 & 340,3 \\
\hline & & ZnAl5Mg3 & 342,9 \\
\hline
\end{tabular}

Tab. 2. Melting temperature of examined solders 
From Fig. 3 it can be seen that the tensile strength ranged from 160 to $200 \mathrm{MPa}$. The highest value of the ultimate strength of $196 \mathrm{MPa}$ reached Zn-Al4 solder and the lowest Rm reached ZnAl1 solder. The results show that the gradual addition of $\mathrm{Al}$ to $\mathrm{Zn}$ increases its strength. When reaching $4 \mathrm{wt}$. \% of $\mathrm{Al}$, which is an alloy of nearly eutectic composition, its strength is highest.
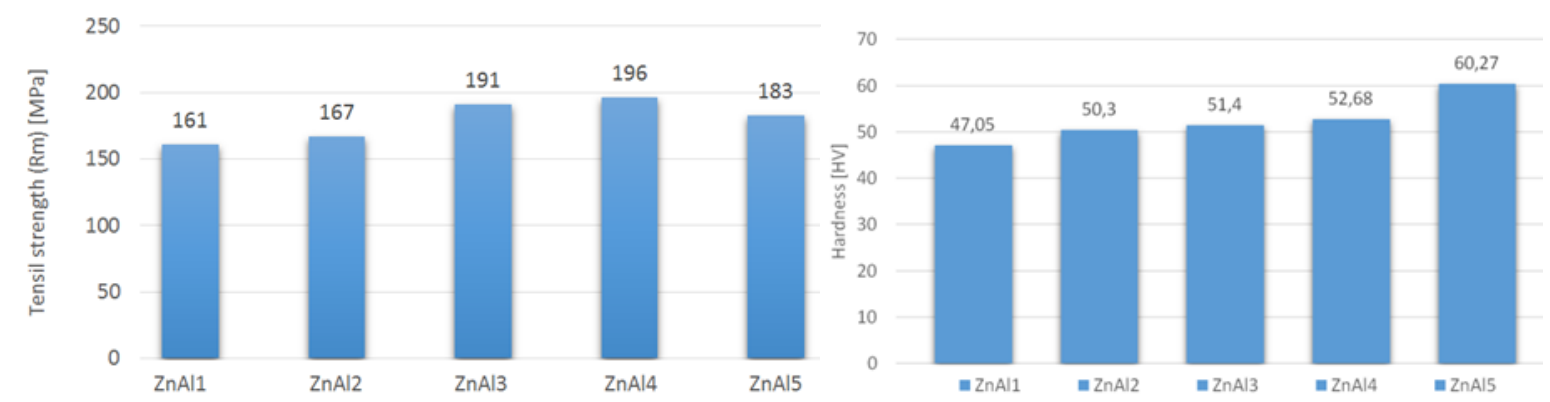

Fig. 3. Tensile strength and Vickers hardness of $\mathrm{Zn}-\mathrm{Al}(1-5)$ solders

Adding of next 1 wt. $\%$ of $\mathrm{Al}$, the strength of alloy decreases again. From the measured values, the lowest hardness reached $\mathrm{Zn}$-Al1 solder with an average hardness $47.5 \mathrm{HV}$ and vice versa highest hardness was observed in $\mathrm{Zn}$ Al5 solder with an average hardness $60.27 \mathrm{HV}$. This means an increasing the hardness with adding of next wt. \% of Al into the $\mathrm{Zn}-\mathrm{All}$ alloy. The Increasing of the hardness of solder was caused because of greater hardness of $\mathrm{Al}$ compared to $\mathrm{Zn}$.
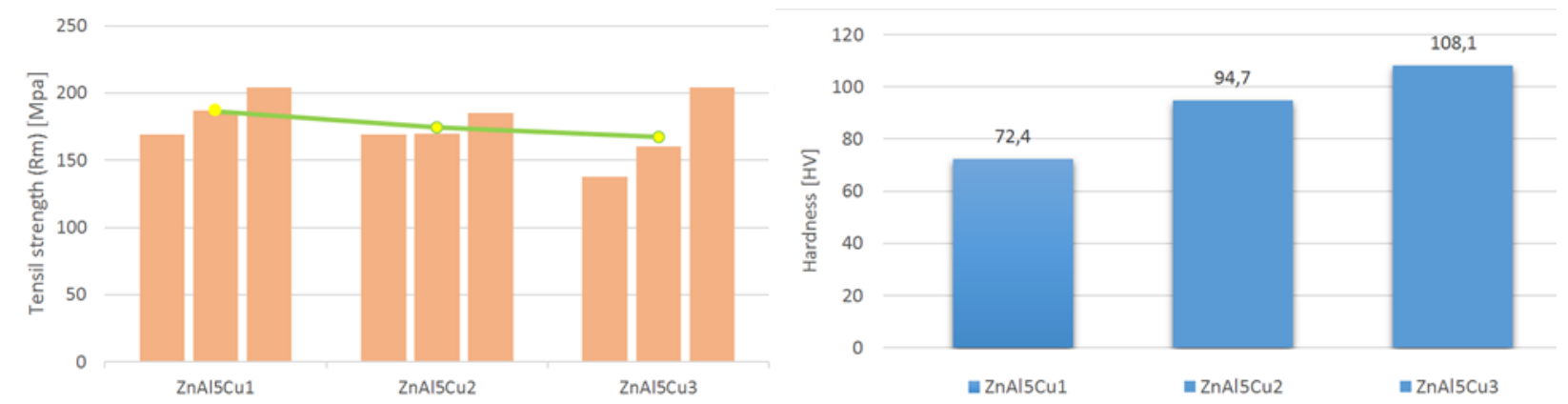

Fig. 4. Tensile strength and Vickers hardness of $\mathrm{Zn}-\mathrm{Al}-\mathrm{Cu}(1-3)$ solders

Three test samples from each solder was prepared to analysing tensile strength (fig. 4) and then subsequently calculated the total average strength. From fig. 4 can be deduced that with a higher percentage of $\mathrm{Cu}$, alloys decreasing their average tensile strength. $\mathrm{Cu}$ and $\mathrm{Zn}$ creates a brittle intermetallic phase $\mathrm{CuZn}_{5}$. By increasing of the content of $\mathrm{Cu}$ in solder, the content of the intermetallic phase is increasing as well. Therefore, the greatest tensile strength reached solder with the lowest content of $\mathrm{Cu}$. The lowest average tensile strength was observed at $\mathrm{Zn}-\mathrm{Al}-\mathrm{Cu} 3$ solder. The results of measuring hardness showing that the $\mathrm{HV}$ hardness increased with increasing percentage composition of $\mathrm{Cu}$ in the $\mathrm{Zn}-\mathrm{Al5}$ alloy. The highest average hardness reached a ternary alloy $\mathrm{Zn}-\mathrm{Al}$-Cu3 due to the formation of intermetallic phases.
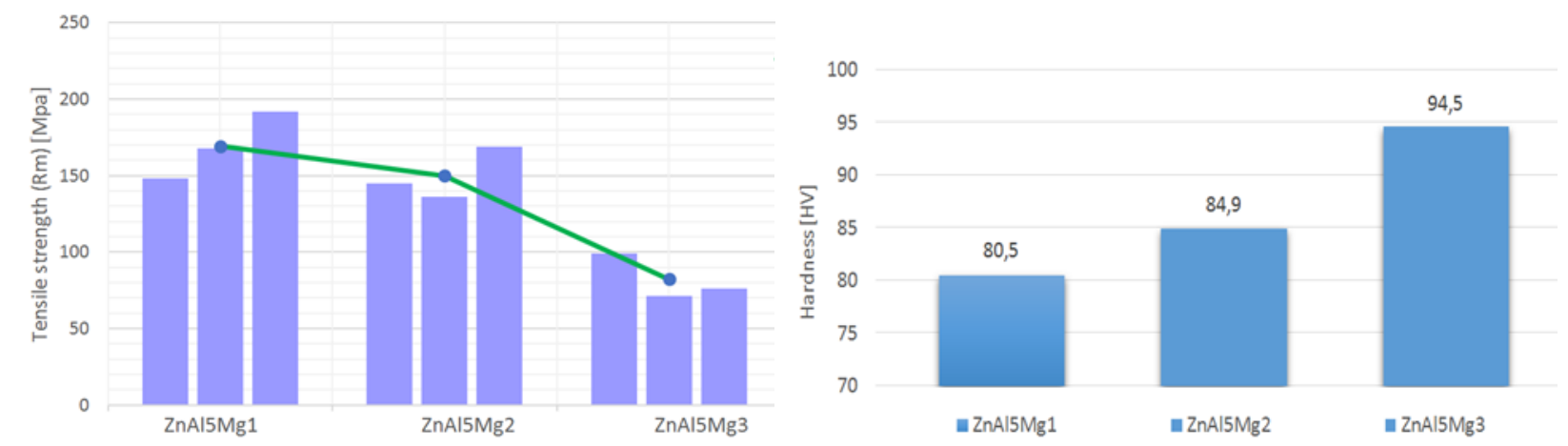

Fig. 5. Tensile strength and Vickers hardness of $\mathrm{Zn}-\mathrm{Al}-\mathrm{Mg}(1-3)$ solders 
Fig. 5 is showing ultimate tensile strength of $\mathrm{ZnAl} 5 \mathrm{Mg}(1-3)$ solder. Three test pieces was used and then from the measured values was calculated average value. From the fig. 5 it can be seen that how tensile strength decreasing with increasing of content of $\mathrm{Mg}$ in $\mathrm{Zn}-\mathrm{Al} 5$ solder. It means that the highest average tensile strength reached $\mathrm{Zn}-\mathrm{Al} 5-\mathrm{Mg} 1$ alloy. This is due to the presence of intermetallic compound $\mathrm{Mg} 2 \mathrm{Zn} 11$, which is at the higher content of $\mathrm{Mg}$ (3\%) dispersed in about $48 \%$ of the volume of the solder.

\section{Conclusions}

The present work dealt with the investigation of the influence of alloying elements in $\mathrm{Zn}-\mathrm{Al}$ alloy on thermal and mechanical properties. Subject of study consisted in the study of effect of $\mathrm{Al}, \mathrm{Cu}$ and $\mathrm{Mg}$ addition on hardness, thermal and mechanical properties. $\mathrm{Zn}-\mathrm{Al}$ (1-5), $\mathrm{Zn}-5 \mathrm{Al}-\mathrm{Cu}(1-3)$ and $\mathrm{Zn}-\mathrm{Al} 5-\mathrm{Mg}(1-3)$ solders were used in experiments.

Based on achieved results, the following was observed:

- addition of alloying elements to $\mathrm{Zn}$ decreased melting temperatures,

- the tensile strength of $\mathrm{Zn}-\mathrm{Al}(1-5)$ had increasing character, in case of $\mathrm{Zn}-\mathrm{Al} 5-\mathrm{Cu}(1-3)$ and $\mathrm{Zn}-\mathrm{Al} 5 \mathrm{Mg}(1-3)$ was observed opposite character due to presentence of intermetallic phases,

- the hardness of examined solders had increasing character. The highest values reached Zn-Al5 (60.27 HV), Zn$\mathrm{Al5Cu} 3(108.1 \mathrm{HV})$ and $\mathrm{Zn}-\mathrm{Al} 5-\mathrm{Mg} 3$ (94.5HV)

It was found that the addition of alloying elements to the $\mathrm{Zn}-\mathrm{Al}$ solder significantly changing the thermal and mechanical properties. In further research, determination of the strength of solder joints is necessary.

\section{Acknowledgement}

The contribution was prepared with the support of APVV-0023-12: Research of new soldering alloys for fluxless soldering with application of beam technologies and ultrasound and VEGA 1/0455/14: Research of modified solders for fluxless soldering of metallic and ceramic materials.

\section{References}

[1] KROUPA, A., ANDERSSON, D., HOO, N. Current Problems and Possible Solutions in High-Temperature LeadFree Soldering. In Journal of Materials Engineering and Performance, Vol. 21(5), 2012, pp. 629-637

[2] HAQUE, A., LIM, B.H., HASEEB, A.S.M.A., MASJUKI, H.H. Die attach properties of Zn-Al-Mg-Ga based hightemperature lead-free solder on Cu lead-frame. In Journal of Material Science: Materials in Electronics, Vol. 23, 2012, pp. 115-123

[3] TAKAKU, Y., FELICIA, L., OHNUMA, I. Interfacial Reaction Between Cu Substrates and Zn-Al Base HighTemperature Pb-Free Solders. In Journal of Electronic Materials, Vol. 37, Is. 3, 2008, pp. 314-323

[4] ALIBABAIE S., MAHMUDI, R. Microstructure and creep characteristics of Zn-3Cu-xAl ultra high-temperature lead-free solders. In Materials and Design, Vol. 39, 2012, pp. 397-403

[5] ZENG, G., MCDONALD, S., NOGITA, K. Development of high-temeprature solders: Review. In Microelectronics Reliability, Vol. 52, 2012, pp. 1306-1322

[6] ZHANG, L., XUE, S., GAO, L., ZENG, G., SHENG, Z., CHEN, Y., YU, S. Effects of rare earths on properties and microstructures of lead-free solder alloys. In Journal of Material Science: Materials in Electronics, Vol. 20, 2009, pp. 685-694

[7] WANG, S., ZHOU, H., KANG, Y. The influence of rare earth elements on microstructure and properties of 6061 aluminum alloy vacuum-brazed joints. In Journal of Alloys and Compounds, Vol. 352, 2003, pp. 79-83

[8] MAHMUDI, R., ALIBABAIE S. Elevated-temperature shear strength and hardness of Zn-3Cu-xAl ultra-hightemperature lead free solders. In Materials Science and Engineering A, Vol 559, 2013, pp. 421-426

[9] XIAO, Y., JI, H., LI, M., KIM, J. Ultrasound-assisted brazing of Cu/Al dissimilar metals using Zn-3Al filler metal. In Materials and Design, Vol. 52, 2013, pp. 740-747

[10] KIM, S., KIM, K., KIM, S., KANG, CH., SUGANUMA, K. Characteristics of Zn-Al-Cu Alloys for High Temperature Solder Application. In Materials Transactions, Vol. 49, 2008, pp. 1531-1536

[11] SHIMIZU T., ISHIKAWA, H., OHNUMA, I., ISHIDA, K. Zn-Al-Mg-Ga Alloys as Pb-Free Solder for DieAttaching Use. In Journal of Electronic Materials, Vol. 28, No. 11, 1999

[12] KOLENAK, R., KOSTOLNY, I., CICKA, R. Research of Fluxless Soldering of High-Purity Aluminium with Solders Type Zn-Al. In Advanced Materials Research, Vol. 905, 2014, pp. 132-136

[13] LEE, J., KIM, K., SUGANUMA, K., INOUE, M., IZUTA, G. Thermal Properties and Phase Stability of Zn-Sn and Zn-In Alloys as High Temperature Lead-Free Solder. In Materials Transactions, Vol. 48, 2007, 584-593

[14] GANCARZ, T., PSTRUS, J., FIMA, P., MOSINSKA, S. Thermal Properties and Wetting Behavior of High Temperature Zn-Al-In Solders. In JMEPEG, Vol. 21, pp. 599-605 